\title{
Living Standard of Academic Staff at Haramaya University
}

\author{
Birhanu Sintayehu $\mathbb{D}^{1}$ and Anwar Ahmed Hussien $\mathbb{D}^{2}$ \\ ${ }^{1}$ Department of Educational Planning and Management, College of Education and Behavioral Sciences, Haramaya University, \\ Dire Dawa, Ethiopia \\ ${ }^{2}$ School of Education and Behavioral Sciences, Worabe University, Worabe, Ethiopia
}

Correspondence should be addressed to Birhanu Sintayehu; biruhamah@gmail.com

Received 23 April 2021; Accepted 28 June 2021; Published 6 July 2021

Academic Editor: Ehsan Namaziandost

Copyright () 2021 Birhanu Sintayehu and Anwar Ahmed Hussien. This is an open access article distributed under the Creative Commons Attribution License, which permits unrestricted use, distribution, and reproduction in any medium, provided the original work is properly cited.

\begin{abstract}
Maslow's theory of the hierarchy of needs suggests that human beings cannot reach the level of self-actualization in the event that their basic needs are not properly fulfilled, i.e., physiological needs and needs related to security. This study is an effort to test the theory against the living standard of instructors of Haramaya University (the researchers explore where academic staff are leveled). A qualitative approach was employed to make an empirical investigation of living conditions of instructors in this particular university and its implication on imparting quality education. To do so, the study was attempted from a phenomenographic viewpoint by identifying four themes of conceptions of living standards of academic staff. These include (1) salary, (2) housing, (3) job security, and (4) self-esteem. The findings of the study revealed that, among other things, poor living conditions of higher education staff, rising living cost, inadequate monthly salaries, derisory housing allowances, and lack of job security made it extremely difficult to change the workplace and resulted in low morale and poor self-esteem of the teaching staff. It is difficult to imagine high-quality education without high-quality instructors. To improve the quality of higher education, basic needs of academic staff must be met; educational inputs must be fulfilled, and the teaching profession should be made more attractive and an important priority of the government.
\end{abstract}

\section{Introduction}

A nation that pays great attention to the promotion of higher education will be destined to grow quickly over time. By higher education, we mean all types of studies after the secondary level, provided by universities or institutions to produce human capital and intensively create new knowledge as well as to transfer it (Education and training policy (ETP)) $[1,2]$.

Likewise, the higher education teacher is one who leads from obscurity to light; in another era, the pioneers of tomorrow, the producer of the specialists, the engineers, the analysts, the attorneys, the mathematicians, the theatre actors, the artists, etc. are all sustained and prepared by instructors [3]. Experienced academic staff are necessary for building and producing a competitive generation. Hence, retention of skilled and experienced manpower is of paramount importance for the continuation and duplication of educated citizens of a country for the future.

A few challenges that confront some of the African Colleges nowadays are inadequate funding and lack of suitable infrastructure, poor staff compensation, and acute shortage of qualified and efficient administrative staff [3]. However, general problems of some of the African universities are inadequate housing, poor salaries, difficulties for the staff to change workplace, and commitment related problems. It has been reported $[3,4]$ that "some of academic staff are on the way to leave their career earlier to their retirement."

Regarding the working conditions and salary payments in many of the higher public universities in Ethiopia, the situation is abysmal, where the physical setting is often uncomfortable, and the mental setting is unpleasant. Insufficient facilities, low (or no) web association, and 
inadequate number of offices and classrooms, as well as heavy workload of instructing, expansive lesson estimates, insufficiency of research facilities and hardware, necessity to lock in other nonremunerated college errands, ineffectively prepared and frequently swarmed workplaces, and need for individual working computers or tablets are among the major issues identified [5].

Many of the Ethiopian higher education institutions have been plagued by multifaceted challenges, which, among others, incorporate the issue of value, quality, independence, responsibility, brain drain, scholarly freedom, need of satisfactory assets and offices, instructors working conditions, compensation and motivations, and by and large administration of individual assets $[6,7]$. No matter how quick the expansion of higher education within the nation is and being paralleled with great policy systems and strategies, the mission of higher education institutions may be realized as being securing, improving, supporting, and doing maintenance of qualified and experienced human capital [8]. There ought to be a fine-tuning between infusions of modern blood into the higher eduction framework, on the one hand, and the maintenance of best minds, on the other [3].

The new road map of Ethiopia education policy discloses poor budgetary benefits of academic staff and their isolated societal status [9]. Be that as it may, the government does not seem to be serious about improving the living condition of academic staff within the institutions of higher learning. In this way, subsequently, the display compensation, motivation, and remunerate framework of academic staff are not as such alluring sufficient to attract those experienced instructors from higher education [9]. The assumption is, from a financial viewpoint, that if the living standards of instructors and civil servants are improved and moved forward, the benefits for country building could be immense. Consequently, many African scholars opt for quitting their jobs in the higher institutions of learning and taking up positions in far better paying institutions before their retirement [10].

As a result, the alarmingly mass migration of qualified academic staff may legitimize poor retention of unfit and mediocre staff within the higher education institutions in Ethiopia. This could perhaps explain the reason for the existence of exceptionally few professors and qualified lecturers in Ethiopian higher eduction today [3]. Brain drain has been, and still is, one of the foremost genuine issues of African higher instruction system. Nigeria, Republic of Congo, Sierra Leone, Zambia, Sudan, and Ethiopia are among the genuinely hit countries in Sub-Saharan Africa. It has been claimed that more African born scientists and engineers are working within the USA than in Africa [5].

Whereas, for the most part, brain drain is related with the displacement of talented manpower to a different nation, Ethiopian higher education is enduring both "external and internal" brain drain. Unfortunately, every year, a huge number of academics are clearing out their employments and the nation and move primarily to North America and Europe, with many of them not returning to the country again. The causes of inside brain drain, being for the most part comparative with that of the outside one, rest more on "push" components than the "pull" ones. Low salary scale, poor working conditions, disappointment with organization, and constrained opportunity for career advancement top the list [5]. Subsequently, Africa is losing its mental capital due to pitiable living conditions and the other factors listed above [4].

Moreover, the salaries of academic staff are far lower than what may be earned within the private and nongovernment organization for the same level of eduction and involvement (Table 1). For further description of Ethiopian higher education, academic staff salary and housing allowance are illustrated in Table 1.

1.1. Statement of the Problem. Indeed, even though comparing salary and benefits in one nation to other nations does not make much sense, because the living conditions of each country are different, higher education institutions of academic staff in Ethiopia are one of the lowest when we compared them with other sub-Saharan African nations. Ethiopian neighbors like Kenya, Uganda, and Tanzania, with more or less the same comparable economic background, pay higher than Ethiopia [3]. This clearly shows how much the educated Ethiopians are disadvantaged when compared with the same professionals in other African countries (Table 2). To bring about improvements in their living conditions, Ethiopian scholars either migrate to other developed nations or leave the higher education institutions, in which they are working to find a better paying job. For further description, comparative salary scales of academic staff among universities in Africa (average gross salary per annum in US \$) are elaborated in Table 2.

Until the mid-1970s, brain deplete had never been considered a hazard to socioeconomic progression in common, and to the advancement of higher education in specifically [11]. As within the rest of Sub-Saharan Africa, the brain drain in Ethiopia has been by and large ascribed to political, financial, and social reasons. Especially, narrow mindedness of different political views by the state and the hunt for jobs with better pay are regularly specified [5].

Even though the Ethiopian government is fully engaged in higher education staff development programs, still, it is shown that there is a constant deficiency of qualified and experienced staff, especially those holding terminal degrees. Within the last decade, the proportion of qualifications of BA/BSc, MA/MSc, and Ph.D. holders serving within the higher eduction is not expanded as anticipated. Although the number of BSc and MSc holders is moderately rising, the number of $\mathrm{PhD}$ holders remained more or less the same or diminished for a long time. Within Haramaya University, in the last ten years, there was not any change identified within the proportion of qualification of BSc, MA/MSc, and Ph.D.

Restricted opportunity for career improvement has been recorded as one of the main reasons that has contributed to the disappointment of, and in turn to the trouble of, higher 
TABLE 1: Ethiopian higher education academic staff salary and housing allowance.

\begin{tabular}{|c|c|c|c|c|c|}
\hline No. & Categories & Basic salary (ETB) & US\$ & House allowance (ETB) & US\$ \\
\hline 1 & Lecturer & 11305 & 287.35 & 800 & 20.33 \\
\hline 2 & Assistant professor & 13926 & 353.96 & 800 & 20.33 \\
\hline 3 & Associate professor & 16979 & 431.56 & 800 & 20.33 \\
\hline 4 & Professor & 20468 & 520.25 & 800 & 20.33 \\
\hline
\end{tabular}

Sources: Haramaya University, finance (January 2021).

TABLE 2: Comparative salary scales of academic staff among universities in Africa (average gross salary per annum in US\$).

\begin{tabular}{|c|c|c|c|c|c|c|c|c|}
\hline & $\begin{array}{c}\text { Ethiopian } \\
\text { public } \\
\text { universities }\end{array}$ & $\begin{array}{c}\text { Makrere } \\
\text { university }\end{array}$ & $\begin{array}{c}\text { University of } \\
\text { Nairobi }\end{array}$ & $\begin{array}{l}\text { University of } \\
\text { Dar es Salaam }\end{array}$ & $\begin{array}{l}\text { Universities } \\
\text { Zimbabwe }\end{array}$ & $\begin{array}{l}\text { University of } \\
\text { Botswana }\end{array}$ & $\begin{array}{c}\text { University of } \\
\text { Namibia }\end{array}$ & $\begin{array}{c}\text { University of } \\
\text { Swaziland }\end{array}$ \\
\hline Professor & 6,243 & 12,972 & 27,612 & 21,228 & 23,447 & 47,198 & 40,026 & 31,967 \\
\hline $\begin{array}{l}\text { Associate } \\
\text { professor }\end{array}$ & 5,178 & 12,428 & 23,197 & 19,460 & 22,774 & 43,990 & 34,604 & 30,033 \\
\hline $\begin{array}{l}\text { Senior } \\
\text { lecturer }\end{array}$ & 4,460 & 10,533 & 18,883 & 15,492 & 18,592 & 40,205 & 30,260 & 25,080 \\
\hline Lecturer & 3,448 & 8,998 & 16,959 & 11,750 & 17,378 & 31,279 & 28,542 & 22,532 \\
\hline
\end{tabular}

Sources: Mushemeza [3].

degree holders. Nowadays, as in numerous other subSaharan countries, the profession in Ethiopia is characterized by low salaries, poor working conditions, the need for regulatory cooperation and scholastic flexibility, packed duty, irrelevant center on investigation and administrations, no work security, and unattractive career path [5].

Subsequently, the present study aimed to fill the following research gaps: first, almost no research studies have been conducted on the living standard of academic staff in higher educational institutions in Ethiopia's public universities and Haramaya University. Second, the uniqueness of the study lies inside the qualitative approach that has been chosen to address the issue. This study attempted to fill the gaps observed within the past studies that had utilized quantitative and regulating approaches. Third, for the past two decades, the Ethiopian higher education system has been developing rapidly, and in spite of this fast expansion, it created a slew of new problems, such as funding deficiencies and weakening of the quality of education [12]. Thus, this study hoped to pinpoint such problems and provide suggestions for their solution. Fourth, it is well known that the number of academic staff is dramatically increasing, and the living costs of instructors are rising, on the other hand. To reconcile such a disparity, this study suggests possible solutions. Finally, if the abovementioned problems of academic staff remain unsolved, our universities may lose their trained and experienced manpower. Hence, this study may contribute to the information available to policymakers, in higher education institutions for helping them make better policies.

1.2. Theoretical Framework. To generate the theoretical framework of the study, Maslow's Need for Hierarchy of motivation theory seems suitable. Maslow claims that human needs may be put into five categories positioned according to priority, which is shown in Figure 1 [13].
The first level deals with the physiological needs of human beings, which are common and basic (Figure 1). As per Maslow's assumptions, an attractive salary and better working conditions, when provided to workers, might fulfil their basic needs such as food, dress, and house, thus assisting them to perform better [14]. This implies that when instructors have inadequate food, water, or shelter to fulfil their physiological needs, they may find it difficult to improve their performance. "When there is no bread, man lives for bread alone." This statement implies that an empty stomach takes priority over the other needs. Thus, Maslow argues that salary or wages of most jobs must be adequate enough to fulfil the physiological needs.

Secondly, security and safety needs imply that each worker requires security against any kind of peril, danger, and unwanted mergers and that institutions have to make their employees feel secure from any kind of danger; they ought to be treated equally and with fairness (Figure 1). Social security and work protections are among the variables that boost work performance of an employee.

The third level deals with the social needs of individuals (Figure 1). We have often heard people saying that man is a social animal and needs social outlets. Neglecting these needs might result in employees' unrest and decreased morale.

The fourth level addresses those needs that promote selfesteem (Figure 1). This need is satisfied when one's work and performances are appreciated and duly compensated for. Proper acknowledgement and appreciation of the work of the instructors in the institutions of higher learning might greatly inspire them to do better and to develop self-respect in them.

The last level is that self-actualization can be personalized in completely unexpected ways in different individuals, and it provides opportunities to the workers in self-growth or individual advancement [15]. 


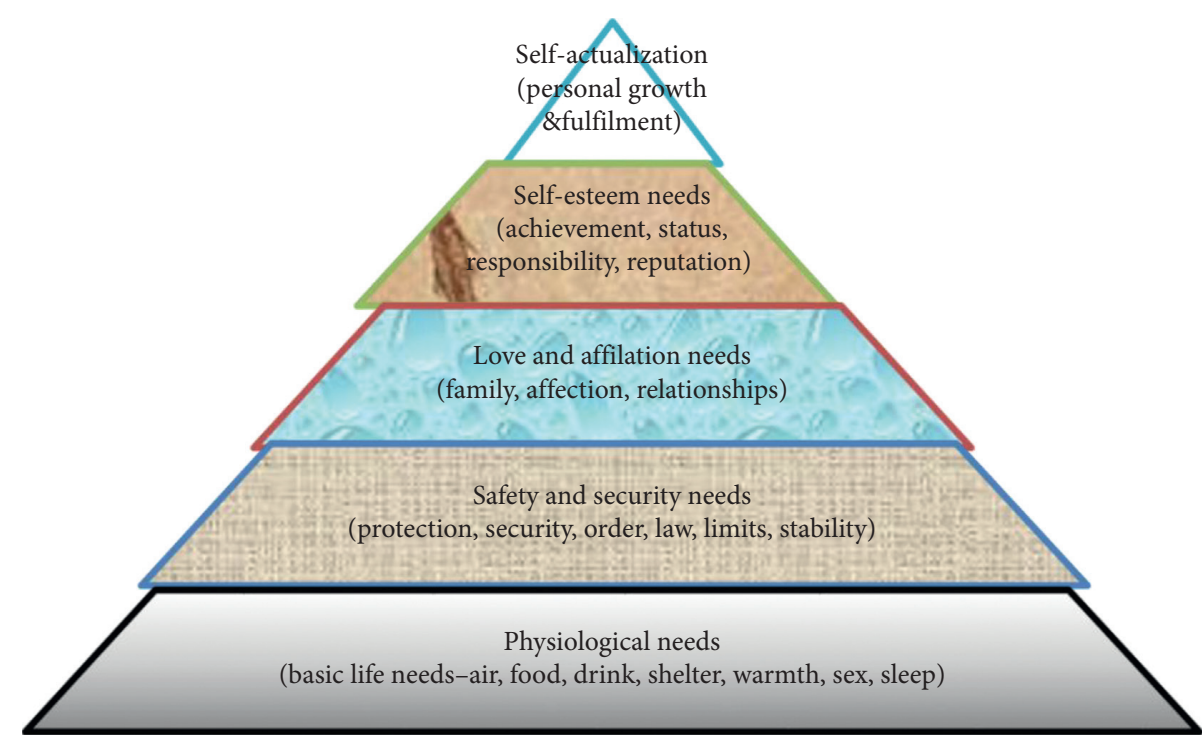

FIGURE 1: Maslow's hierarchy of needs (five-stage model). Source: Rue and Byars [13].

The theory proposes that people cannot reach self-actualization level if their basic needs are not met, including physiological needs and needs related to security. It proposes that people cannot reach self-actualization level within their profession or personal lives if their basic needs are not satisfied, i.e., physiological needs and needs related to security $[16,17]$. Having briefly described Maslow's hierarchy of needs, the current researchers feel that, looking at the situation in the Ethiopian higher education institutions in general and Haramaya University in particular, this theory is pertinent to help us assess the living conditions of higher education instructors and see whether introducing positive changes in those conditions could actually enhance the effectiveness of the staff and enhance their performance.

1.3. Basic Research Questions. The main objective of this research was to investigate the living standards of academic staff of Haramaya University, Ethiopia. Consequently, this study was an endeavor to answer the following basic research questions:

(1) How does the academic staff of the Haramaya University perceive their current monthly salary and other benefit packages, in relation to their day-to-day living expenses?

(2) What does the academic staff of the Haramaya University think about the housing allowance currently provided to them in relation to the living costs in the country?

(3) Does the academic staff of the Haramaya University feel secure in their teaching profession?

(4) Does the academic staff of the Haramaya University feel proud of their position in society?

\section{Methodology}

2.1. Design and Approach. The interpretive phenomenological design of the qualitative research approach was employed to conduct this study. Interpretative Phenomenological Analysis (IPA) is suitable for analyzing the collected data as it gives clear steps and a position in understanding and deciphering the experiences of the included informants [18]. When utilized as an approach, the IPA primarily appears to be of informant-oriented nature, meaning that it allows the informants to express their narrations without reservation and distortion. The IPA's main objectives are to narrate the informants' current experiences through their honest participation [19].

2.2. Study Groups and Inclusion Criteria. Nine faculty members were selected purposively for this study. The selection was based on the suggestion by Polkinghorne [20] who advised that the participation of five (5) to twenty-five (25) individuals who have experienced the phenomenon shall be adequate enough for undertaking the study. The nine (9) selected participants in the study narrated their current experiences as academic staff of the Haramaya University. The conviction was that these nine academic staff were well informed about the subject of the study. The inclusion criteria of the participants of the study were the academic rank of instructors. Of these nine selected participants, three were associate professors, three were assistant professors, and the last three were lecturers. The second inclusion criterion was the years of service to select each faculty member from the abovementioned ranks. All the nine participants had more than three years of service record at the time the data were gathered. The researchers believed that this composition of the study group could provide the information needed for this research undertaking. 
Self-generated and open-ended interview questions were employed to collect data from the participants (Table 3). Participants answered the interview guide questions through face-to-face conversation. Interviews were conducted in a formal situation, the questions were asked one after the other, and the subjects answered the questions freely. The following are the profiles of the participants with their assigned numbers (\#), i.e., interviewee\#1, interviewee\#2, interviewee\#3,..., etc., which are described in Table 3.

2.3. The Instrument of Data Collection. To investigate the subjective experience of the participants, a semistructured interview was conducted. The research questions have been categorized into four major parts, which are directly in line with the four themes of the study. The first part looked into the standard of living of academic staff by their current monthly salary and other benefit packages, with a semistructured one meeting direct question. The first question was "How does the academic staff of the Haramaya University perceive their current monthly salary and other benefit packages, in relation to their day-to-day living expenses?" The second part was on the housing allowance, with a semistructured one meeting direct question. The question was, "Does the academic staff of the Haramaya University think about the housing allowance currently provided to them in relation to the living costs in the country?" The third question was on job security; the question asked was, "Does the academic staff of the Haramaya University feel secure in their teaching profession?" The last part emphasized the selfesteem of academic staff in their teaching profession. The question asked was, "Does the academic staff of the Haramaya University feel proud of their position in society?" The Instrument was checked for substance and built legitimacy by two professionals from the College of Education and Behavioural Sciences of Haramaya University.

2.4. Procedures of the Study. Before proceeding with data collection and analysis, approval was sought from the University Research Vice President for Research Affairs, and then permission was obtained from the university's concerned officials. The participants were informed about the date and time of interview one week before the interview session. Written and signed consent letters were obtained from the participants in this study, before they were engaged in the interview sessions. The interview session for each participant took approximately 30 to 40 minutes. The interview was conducted in Amharic. At that point, after the session was over, it was translated into English. The composed content was then deciphered into English with greatest precision. Then, the information was sorted and filtered theme by theme for the next stage of the analysis.

2.5. Data Analysis. The collected interview data were translated, coded, categorized into four themes, and based on the research questions. These were as follows: How does the academic staff of the Haramaya University perceive their current monthly salary and other benefit packages, in relation to their day-to-day living expenses? What does the academic staff of the Haramaya University think about the housing allowance currently provided to them in relation to the living costs in the country? Does the academic staff of the Haramaya University feel secure in their teaching profession? And does the academic staff of the Haramaya University feel proud of their position in society?

First, the researchers perused all the interview transcripts and checked the parts, where academic staff explained their basic thoughts about standards of living academic staff. Then, the researchers highlighted the selected part of the transcripts and begun figuring out those categories of the conception of academic staff standards of living academic staffs while rereading the transcripts. Finally, the researchers created "qualitatively different' categories of depictions that were utilized to characterize the conceptions of standards of living academic staff of these Haramaya University.

2.6. Ethical Considerations. As was clarified recently, the information was collected after the composed consent of the respondents was gotten. In doing so, first, the researchers approached the participants and talked to them about the study. Second, the participants were informed about the purpose and procedures of the study. Third, the researchers sought the consent of the participants and their permission to use audio taping for recording the interviews. Meanwhile, the researcher assured the respondents that their participation in the study will be based on their willingness and will be voluntary and that they could quit their participation at any stage in the study. This is to emphasize that voluntary participation of the study groups and consensus between researcher and respondents' confidentiality and anonymity were taken into consideration and assured. The researchers employed numerical symbols $(\# 1, \# 2, \ldots, \# 9)$ in making the necessary identification and confidentiality over using their names to report the obtained data from the participants.

\section{Findings}

3.1. Theme 1: Salary and Other Benefit Packages. Most of the respondents reported that the salary that the academic staff receive is extremely inadequate. As per one account, the response was the following.

We pay $30-35 \%$ tax to the government. On top of that we pay $15 \%$ tax on whatever we buy from the market. The minimum rent for a small room in Harar is 1500ETB. After paying the tax and the rent, what amount of money are we left with? How are we expected to feed ourselves and our families by the money we are left with? If your salary is about 11305ETB (\$282.62), you have already lost $50 \%$ of it to the tax. You are left with only 5652.5. From this amount, we need to deduct another 1500 for the house rent. What are we left with? Can one feed one's family and educate and clothe one's children on this amount? We are human beings! We cannot survive by eating Shiro, pasta, macaroni. . . throughout the year. (\#1) 
Table 3: Profile of the respondents.

\begin{tabular}{lccc}
\hline Pseudonyms & College & Academic rank & Teaching experience in years \\
\hline$\# 1$ & College of Law (COL) & Lecturer & 6 \\
$\# 2$ & College of Computing and Informatics (CCI) & Lecturer & 4 \\
$\# 3$ & College of Business and Economics (CBE) & Lecturer & 3 \\
$\# 4$ & College of Natural and Computational Sciences (CNCS) & Assistant professor & 10 \\
$\# 5$ & College of Education and Behavioural sciences (CEBS) & Assistant professor & 7 \\
$\# 6$ & College of Veterinary Medicine (CVM) & Assistant professor & 8 \\
$\# 7$ & College of Agricultural and Environmental sciences (CAES) & Associate professor & 11 \\
$\# 8$ & College of Social Sciences and Humanities (CSSH) & Associate professor & 13 \\
$\# 9$ & College of Health and Medical Sciences (CHMS) & Associate professor & 12 \\
\hline
\end{tabular}

They also explained that the salary of higher education academic staff is less than the salary of people in many other institutions.

A Bank manager's salary is almost 26000 birr. Similarly telecommunication and electric power managers get about 25, 000 birr and 32, 000 respectively per month. Customs manager salary is 40,000 birr. . In contrast, one Ph.D. holder's salary is only about 14, 000 Ethiopian Birr (ETB). Our lifestyle assures reality. We cannot afford to buy a car or our own house. . one senior lecturer and freshman lecturer's salary is equal. Experience should be rewarded, and seniority has to be considered in the payment structure. (\#8)

It was further emphasized that, in comparison with the other staff in teaching profession, the higher education staff were paid the least.

Even though the quality of education is a public concern for which all of this generation is responsible, we have suffered in so many different ways. For example, more than half of higher education staff are master's holders or above and they earn an average salary of about 8000 ETB. Whereas, primary school a principal, holding a BA/BSc degree earns about 15000 plus a number of other benefits. This is so unfair. (\#2)

They further argued that, as per the information available to them, Ethiopia's lecturers and professors are amongst the world lowest paid. For instance,

A lecturer in Kenya typically earns around Kish 179839 (\$1657.07) average monthly salaries, comprising of housing, transport, and other allowances. Experience level also has values for salary increment. Whereas Ethiopian lecturers are paid 11, 305 ETB (\$307.51) monthly salaries without any allowances which is less than 5 times that of Kenya. Experience level also has no values for salary increment. (\#8)

Some of the participants stated that even though the Ethiopian government has adjusted a new salary scale "Job evaluation and grading" (JEG) in 2018/19 with an average of 500 ETB, the expenses have increased severalfold. They felt that, instead of increasing their salary by a small sum, it would have been far more effective if the government could find a way to fix the market volatility. "The funny thing is that when the government increases the salary by 300 birrs, the landlord increases the rent by 500 ETB.” (\#3)

Still, others claimed that the amendment approved for university teachers in July $2018 / 2019$ is not a salary scale adjustment, nor salary increases.

Compared to other institutions, the government's salary increase for university teachers is very small. Other government employees in other institutions benefited more than their salaries. Thus, salary increases and housing allowance for university teachers should be increased; pocket money for teachers studying for masters and the doctoral degree should be adjusted.(\#4)

They finally claimed that other benefit packages are not sufficient for those teachers on study leave of masters and doctoral degree: "The pocket money and research facilities for when teachers study for master's and doctoral degree is insufficient and very inadequate (1500 to 2000) ETB.” (\#9).

3.2. Theme 2: Housing. In the second theme, housing is identified as one of the basic phenomena for assessing the standard of living of academic staff. The majority of those interviewed were of the opinion that the housing allowance currently paid for higher education instructors is not enough. For example, an instructor explained how the housing problem is critical in the following words.

I know the amount of money paid to lecturers for housing allowance since 2002 G.C. The amount is fixed and it is only 800 ETB per month. However, in 2002, one U\$ Dollar was around 7 ETB. The allowance is still the same today, but one U\$ Dollar is now equivalent to 38 ETB. How on Earth can this be called fair? What kind of house can you rent with 800 birrs? Funny enough, the housing allowance is still the same and is subjected to the taxation of about 35\% (220 birrs) from 800 birrs. In other words, we are receiving a net amount of about 520 birrs for housing allowance. What kind of a house can you get to live in for 520 birrs a month? On average, the rent of a house costs around 3, 500 birrs per month. On another issue, I know that previously, lecturers who went abroad for education purposes could come back with an 
automobile free of tax but it is prohibited now, why is that so? A scholar who gained knowledge from the top Western Universities and who came back to serve his motherland with his knowledge should be encouraged with such subsidies. (\#2)

In addition, they stated that housing allowance and related benefit packages are still extremely inadequate when we compare Ethiopian lower level teachers with the other research institutes with higher education academia. It is illustrated as follows.

In so far as the housing issue is concerned, from primary to college level the government provides housing allowance for instructors. However for instructors they said that the federal government would provide facilities for them." Thus, the most victimized citizens in the country are the teachers of higher education. We have no opportunity to have a long-term loan from banks whereas the other sectors have. College and secondary school teachers have the right to have a free home, construction right in their respective town, but we do not have. With regards to house allowance in Ethiopia any research institution's employees' minimum house allowance is 2, 500 , whereas higher institutions pay a gross amount of 800 ETB and around 520 ETB net. (\#6)

The participants in this study also mentioned that even though they have raised this question several times while discussing the matter with the government officials, very little has been done to address this matter.

No one will listen to you if you talk about wages, housing, and land in higher education institutions that are rife with corruption. We asked and raised these questions several times, but our problems are not addressed. (\#5)

3.3. Theme 3: Job Security. The respondents in the third theme perceive the standard of living of academic staff from a job security viewpoint. They conceived that higher education instructors do not have job security. For example, one instructor stated the following.

Higher education professors do not have security for their future in the teaching profession; professors maybe renting a house in a secluded area, and their children will often get upset every time he knocks on their door. This is a fact that we are obersving the university professors living in Addis Ababa, are facing. Perhaps people in our state may be able to rent condominiums. When you arrive at the intersection, you must take off your hat and stand on one foot on a highway, packed like an object, and take what is next to you. I urge you not to miss out on this opportunity for cooperation and organization that we have always wanted. (\#9)
Others further explained their future plan to remain in teaching until they are eligible for retirement and reacted as follows.

The homeless doctor is on the streets. Education is a key stimulator of development, but without the promotion of teachers and providing them with job security, very little will be achieved in this field. The current salary of teachers discourages many enthusiastic aspirants to stay in higher education. Thus, we do not have job security, and we do not want to stay in this profession unless the government makes reforms. Most of us want to leave teaching profession unless we get something better than before. (\#7)

Another participant in this study who was interviewed said the following.

In the present payroll system, a Ph.D. holder may end up his/her life without owning shelter. On the other hand, a degree holder district official may possess 3 or 4 houses. There is a need to change the scenario otherwise higher education will start losing skilled manpower gradually. The other issue that needs to be reconsidered by the government is forcing the staff to commit for postgraduate studies double of their study time (two year MSc/MA study leave should be expected to serve the University for Four years and a four year Ph.D. study leave should be expected to serve the university for eight years). This policy greatly restricts the movement or academic freedom of the eligible candidates as far as one is working in the country? (\#1)

3.4. Theme 4: Self-Esteem. The interviewees in the last theme conceived the standard of living of academic staff from a selfesteem viewpoint and how does academic staff feel proud of their position in society. They conceived that higher education instructors do not feel proud as past years. For example, one instructor explained the following.

In the past, when a teacher was celebrated, he was called a "teacher who took our bride's curry or a teacher who took our bridal sweater." That is why it seems that our bridegroom has taken a teacher and teaching profession was highly respected. The current teacher's standard of living is very low in social acceptance, as well as politically and economically. As teachers we do not earn enough to build a house; buy a car or have a decent life. Once when I was sitting in a cafe with a friend drinking coffee, two elderly friends were by our side and we did not know what they were talking about, but one of them shouted, silence is acceptance. We kept silent about our issues, and the government forgot us. We need to show up; ending the silence is the means to attain our goals. Looking for the officials to understand our demands by themselves is a wrong assumption, collective demands require collective actions. (\#5) 
Similarly, another instructor explained how the teachers are socially segregated. He stated: "It is not exaggerating if I say we are the most underrated and underdeveloped section of the society. We are not only underdeveloped as compared with other African universities but also we are the least paid compared to elementary, high school and preparatory schools staff of the country."

In the same way, one more instructor said the following.

Ethiopia is a country where the teaching profession-the mother of all professions is not respected. Let's leave the urban teacher and see the rural teacher. I had the opportunity to see him leave town. I do not think we live in this century, we think we are in the 19th century. I recently went to an Addis Ababa circuit. I met my old school friend. This friend of mine has worked in the countryside before. Tears are well up in his eyes as he remembers his life. He just thanked God that he had paid for it. He told me that I worked as a teacher and now I will be paid. You will find a woman brewing coffee along this road instead of staying in the teaching profession because of the low salaries and the lack of appreciation for the dedicated services of the teachers in our nation. (\#6)

A few of those who were interviewed also emphasized the role that education plays in empowering the masses and the opportunities it provides for bringing about transformation in the lives of people. According to one of them, we have the following.

Education is the great engine of personal development. It is through education that the daughter of a peasant can become a doctor, that the son of a mineworker can become the head of the mine that a child of farm workers can become the president of a great nation. It is what we make out of what we have, not what we are given, that separates one person from another. We teachers are the father of all work sector but we are blow all the other sectors. (\#7)

Another instructor underscored how much the higher education teaching profession has been deteriorating and how difficult it has become to work in such institutions.

Let me tell you facts about two friends of mine who graduated from the same department about 7 years ago. One was graduated with 2.9 CGPA and joined a bank whilst the other with Great Distinction preferred to be a university teacher because he loves teaching very much. And then they compared their first month's net salary that the one who joined the bank was paid 4, 200 birr and the teacher got 2, 800 birr. Now the banker became a bank manager, getting more than twenty thousand, offered an automobile, got a loan, and purchased a house. And he still holds a BA degree. In contrast, the teacher now has a master's degree, but he gets $1 / 3$ of his friend's salary, no house, and no automobile. This teacher is suffering from loving his profession. (\#3)

\section{Discussion}

In this study, attempts were made to explore the living standard of teaching staff in the institutions of higher learning of Ethiopia, Haramaya University focus. A comprehensive analysis of the understanding of the distinctive standard of scholastic staff was developed from the investigation. Four themes of conceptions of living standard of academic staff have been highlighted; these included (1) salary, (2) housing, (3) job security, (4) and professional respect of academicians.

The first key finding of the first theme was that the present-day salary structure for the teaching staff in the higher institutions of learning in Ethiopia is still inadequate to retain talented and experienced instructors. Indeed, even though comparing salaries and benefits of other public employees with each other in different countries of the world does not make much sense due to the variations in living conditions of each nation, the teaching staff in the higher institutions in Ethiopia are amongst the lowest paid when compared with the other sub-Saharan African nations. This finding replicates a study conducted by Tettey [4], which states "disappointment due to dissatisfaction with pay rates may be a key factor that is undermining the commitment of academician to their careers and, subsequently, most of them are compelled to leave the teaching profession if they get a better job than their current position." One of the reasons for the current decline in education in the country is the incompetence of teachers. This is due to the high turnover of experienced instructors, lack of proper pretraining, and continuous professional development [1]. Similarly, Mushemeza [3] and Yizengaw [21] argued that: "African universities face numerous challenges, first is the factor of funding higher education inadequate remuneration in form of salaries has resulted into several unfortunate consequences particularly resignation to join better-paying institutions after being sponsored for advanced degrees." In the same way, Woldegiyorgis [5] says "dissatisfaction with salaries is a key factor undermining the commitment of academics to their institutions and careers and, consequently, their decision or intent to leave."

Thus, low salary scale, poor working conditions, dissatisfaction with the financial management system, the restricted opportunity for career improvement, and inaccessibility of research funds were rated as top hampering factors that academic staff are currently facing.

The second important finding of the second theme was that housing allowance currently paid to the academic staff is about $16 \%$ of the current market demanding from each instructor to rent a house. Actually, this violates the country's constitution: "the government shall endeavor to protect and promote the health, welfare and living standards of the working population of the country" [22]. Higher education's teachers ought to think, research, read, and prepare their lesson plans for teaching subject areas. Instead, they are worried day and night about their daily bread for themselves and their family, and this mental preoccupation prevents them from making enough preparation for courses that they teach. For obvious reasons, people in the teaching 
profession need mental well-being and psychological adjustments.

The third main finding of this research undertaking was that job security was seen as one of the significant pillars of the standard of living condition that seriously affects the life of the academic staff of higher education institutions. Higher education teachers do not feel secure in their jobs; they cannot transfer themselves from one university to another without finishing their study leave commitment, which is double of their study leave years. This may violate the Ethiopian constitution and the democratic right of an instructor "no one shall be required to perform forced or compulsory labor" [22]. In fact, most of the academic teachers in universities across Ethiopia are forced to fulfil their commitments before they are allowed to move to another institution. The reason behind this is that most of the teachers in Ethiopia are economically too poor to finance their high-level education. If they wish to pursue their higher education, the only option before them is to accept the commitment agreement with a university to serve twice the number of years it took them to complete their study after graduation. On the other hand, the Ethiopian constitution clearly indicates "People have the right to full consultation and to the expression of views in the planning and implementations of environmental policies and projects that affect them directly" [22]. Lack of health insurance coverage, lack of interest-based loan service for basic needs (house construction and car), unattractive career path, unpleasant working conditions and remuneration, and challenges of brain drain are the major factors that contribute their share to job insecurity of academic staff of the institutions of higher learning. Subsequently, it appears basic to have a teachers' retention approach that would conceive benefits for instructors and draws in the most excellent minds to the profession.

The fourth primary finding of the study was lack of professional self-respect or low self-esteem in the teaching profession. This is identified as one of the critical problems that negatively affect the standard of living of scholastic staff of higher institutions of learning. The crumbling of social values and demeanors that undermine the teaching profession and lack of respect for the teaching profession are amongst the major issues that almost everybody effortlessly emphasized that they are causing the deterioration in the teaching profession [23]. Similarly, instructors play a vital role in the advancement of civilization, and the teaching profession is the mother of all professions, but they are poorly regarded by the population at large, and they are socially isolated and foremost underrated, unrecognized, and undeveloped segment of society $[3,23]$.

\section{Conclusions}

The main purpose of this study was to explore the living standards of academic staff in the higher institutions of learning in Ethiopia, with special focus on Haramaya University. Based on the results of the study, the following conclusions were drawn:
The following four criteria were considered for assessing the standard of living of higher education teaching staff, (1) salary, (2) housing, (3) job security, (4) and low self-esteem due to the poor professional respect for academicians. The inadequate salary that does not consider the current cost of living in the country makes teachers incapable of meeting their expenses or fulfilling their desire of constructing a house. The house rent allowance provided by the government is far below the actual rent of a decent accommodation in the country. To rent a suitable house, the staff are required to pay seven times more than what is being offered currently by the government. Most of the teachers do not feel comfortable performing their duties; they are working because of the commitment they signed before they opted for the government sponsored higher education [24]. Thus, a job security issue for most of the teaching staff is a major issue. The last factor was the low social status of teachers, lack of social acceptance due to poor social and economic status. Some of those who were interviewed said that the expansion of higher education has not made education more relevant to the expected level. Therefore, the quality and appropriateness issues need to be addressed by designing a system that can solve these problems $[1,25]$.

"At the entrance gate of a university in South Africa the following message was posted for contemplation" as indicated by Ndaguba et al. [26]. "Destroying any nation does not require the use of atomic bombs or the use of long-range missiles. It only requires lowering the quality of education and allowing cheating in the examination by the students." "Patients die at the hands of such doctors; buildings collapse at the hands of such engineers, money is lost at the hands of such economists and accountants, humanity dies at the hands of such religious scholars. Justice is lost at the hands of such judges ... the collapse of education is the collapse of the nation." Quality education is nothing without quality manpower. To improve the quality of life of the academic staff of higher educational institutions, we need to bring about great administration reforms; essential needs of instructors must be met; instructive inputs must be fulfilled, and the teaching profession ought to be made appealing and get due attention from the government.

\section{Recommendations}

Based on the above conclusions, which were drawn from the results and discussion of the study, the following suggestions were recommended for future improvement:

(1) The Ethiopian government ought to come up with a new teachers' salary scheme that is at par with those of individuals with the same qualifications working in banks and other government institutions. This needs the immediate attention of those in authority if they wish to retain the services of the teaching staff serving in the higher institutions of learning.

(2) In addition to salary increment for improving the life of academic staff in public universities, the following suggestions were offered. Health insurance coverage needs to be granted, tax deduction must be 
reexamined and made less burdensome, and loan facilities must be provided by the government for satisfying the basic needs of teachers such as buying a house or a car and the coverage of the pension contributions.

(3) It would be wonderful if the government could provide free of charge quality education to children of the academic staff in the institutions of higher learning.

(4) Furthermore, to boost the self-esteem of the academic staff of higher education, the government is advised to take initiative to fulfil the basic needs of instructors, their academic freedom to be guaranteed, and their scientific research findings utilized as input for policymaking, and their voice should be heard.

(5) We also suggest that the government should help the higher education teachers form their own independent professional association. The members in this association would represent each university in the country and would pursue instructors' rights and privileges.

\section{Data Availability}

The data used to support this study are included in the article.

\section{Conflicts of Interest}

The authors declare that they have no conflicts of interest.

\section{Acknowledgments}

The authors thank Professor Sohayl Mohajer for his expertise and professional guidance throughout all aspects of the study and for his support in editing the manuscript.

\section{References}

[1] ETP, Federal Democratic Republic Government of Ethiopia, Education \& Training Policy, Addis Ababa, Ethiopia, 2020.

[2] J. Blanke, The Africa Competitiveness Report 2011, Vol. 62873, The World Bank, Washington, DC, USA, 2011.

[3] E. D. Mushemeza, "Opportunities and challenges of academic staff in higher education in Africa," International Journal of Higher Education, vol. 5, no. 3, pp. 236-246, 2016.

[4] W. Tettey, "Academic staff attrition at African universities," International Higher Education, vol. 44, pp. 6-8, 2006.

[5] E. T. Woldegiorgis and M. Doevenspeck, "The changing role of higher education in Africa: a historical reflection," Higher Education Studies, vol. 3, no. 6, pp. 35-45, 2013.

[6] T. Semela, "Private higher education in Ethiopia: Peril and promise," The Ethiopian Journal of Higher Education, vol. 4, no. 1, pp. 85-91, 2007, http://ejol.ethernet.edu.et/index.php/ EJHE/article/view/280.

[7] S. Chattopadhyay, "Academic freedom, institutional autonomy and institutionalising accountability: a reflection on the national education policy," An Interdisciplinary Social Science Journal of Criticism, Practice and Theory, vol. 4, no. 1, pp. 1-23, 2020.
[8] C. M. O. Granero, "The internationalisation of higher education in Ireland and its impact on language policy: a qualitative document analysis," TEANGA, the Journal of the Irish Association for Applied Linguistics, vol. 27, pp. 147-173, 2020.

[9] T. Tirussew, A. Amare, O. Jeilu, W. Tassew, D. Aklilu, and A. Berhannu, "Ethiopian Education Development Roadmap (2018-30): An Integrated Executive Summary: Draft for Discussion, Addis Ababa," 2018, http://planipolis.iiep.unesco. org/sites/planipolis/files.

[10] N. V. Varghese, "Governance reforms in higher education: a study of selected countries in Africa," in Policy Forum on Governance Reforms in Higher Education in Africa, Nairobi Kenya, UNESCO, Paris, France, 2013.

[11] D. Loonin and J. M. Morgan, "Aiming higher: looking beyond completion to restore the promise of higher education," SSRN Electronic Journal, vol. 48, p. 423, 2019.

[12] R. Mitchell, "The implications of school improvement and school effectiveness research for primary school principals in Ethiopia," Educational Review, vol. 67, no. 3, pp. 328-342, 2015.

[13] L. W. Rue and L. L. Byars, Management Skills and Application, McGraw Hill Education, New York, NY, USA, 13th edition, 2009.

[14] D. P. Moynihan, S. K. Pandey, and B. E. Wright, "Prosocial values and performance management theory: linking perceived social impact and performance information use," Governance, vol. 25, no. 3, pp. 463-483, 2012.

[15] A. Suleiman Abdulrahman and X. Hui, "Implication of motivation theories on teachers performance in the context of education system in Tanzania," International Journal of Secondary Education, vol. 6, no. 3, pp. 46-53, 2018.

[16] F. C. Lunenburg and A. Ornstein, Educational Administration: Concepts and Practices, SAGE Publications, Thousand Oaks, CA, USA, 2021.

[17] E. Mlaki, "Drawbacks of cost sharing in secondary education in semi-arid areas in Tanzania: experience from manyoni and dodoma rural districts," International Journal of Education and Research, vol. 2, no. 11, pp. 205-2014, 2014.

[18] J. A. Smith, M. Jarman, and M. Osborn, "Doing interpretative phenomenological analysis," Qualitative Health Psychology: Theories and Methods, pp. 218-240, 1999.

[19] A. Alase, "The interpretative phenomenological analysis (IPA): a guide to a good qualitative research approach," International Journal of Education and Literacy Studies, vol. 5, no. 2, pp. 9-19, 2017.

[20] D. E. Polkinghorne, "Phenomenological research methods," in Existential-phenomenological Perspectives in Psychology, pp. 41-60, Springer, Berlin, Germany, 1989.

[21] T. Yizengaw, "The status and challenges of Ethiopian higher education system and its contribution to development," The Ethiopian Journal of Higher Education, vol. 1, no. 1, pp. 1-19, 2004.

[22] E. Constitution, "Federal Democratic Republic of Ethiopian Constitution. Proclamation No. 1/1995 Proclamation of the Constitution of the Federal Democratic Republic of Ethiopia," 1995, http://www.ilo.org/dyn/natlex/natlex4.detail?p_ lang=en\&p_isn=47312.

[23] Z. B. Gurmessa and J. T. Bayissa, "Pay and performance in Ethiopian higher education: implications towards staff motivation and engagement," European Journal of Business and Management, vol. 7, no. 7, pp. 328-339, 2015.

[24] I. Virca and M. L. Rusu, "Study on measuring the performance of the education system with the help of key performance indicators," Buletin Stiintific, vol. 25, no. 2, 2020. 
[25] M. N. Kahsay, "Quality and quality assurance in Ethiopian higher education," Critical Issues and Practical Implications, 2012.

[26] E. Ndaguba, E. O. C. Ijeoma, G. I. Nebo, A. C. Chungag, and J. D. Ndaguba, "Assessing the effect of inadequate service provision on the quality of life of the poor: a focus on justice and education in Nigeria," Cogent Social Sciences, vol. 4, no. 1, pp. 1-16, 2018. 